\title{
COMBATING THE BRIBERY OF FOREIGN PUBLIC OFFICIALS AND THE "ART OF PERSUASION": THE CASE OF ALSTOM AND THE ENERGY SECTOR
}

\author{
John Hatchard*
}

\begin{abstract}
This article explores some of the developing strategies designed to tackle the supply side of transnational corruption through the "Art of Persuasion" i.e. how to "persuade" commercial organisations, no matter how powerful, to commit to good governance and integrity in their business. In doing so, it uses Alstom SA (hereinafter Alstom) as a case study. The article is divided into three parts. Part 1 explores some of "persuasive" techniques designed to combat the bribery of foreign public officials and to enhance corporate good governance and integrity. Part 2 explores some of the lessons and challenges from the Alstom case whilst Part 3 contains a Conclusion which re-visits the "Art of Persuasion".
\end{abstract}

KEY WORDS: Corruption; Bribery of Foreign Public Officials; 'Art of Persuasion'; Debarment; Alstom; Bribery Act 2010; Foreign Corrupt Practices Act; World Bank procurement guidelines.

\section{THE CHALLENGE}

Combating corruption and enhancing good governance are neither the sole preserve of the public sector nor simply national issues. Today the private sector wields immense economic power and political influence both nationally and internationally and it is in those sectors where the

* Professor of Law, Buckingham Law School; Co-Director, University of Buckingham Centre for Extractive Energy Studies (UBCEES). This is an updated and expanded version of a paper given at a UBCEES conference. E-mail: john.hatchard@buckingham.ac.uk 
State and the private sector interact and intersect that are often characterised by corrupt practices. ${ }^{1}$

This is particularly the case in the energy and related sectors. For example, some 3.5 billion people live in countries rich in oil, gas or minerals. As the World Bank has emphasised, "with good governance and transparent management, the revenues from extractive industries can have a transformational impact on reducing poverty and boosting shared prosperity, while respecting community needs and the environment". ${ }^{2}$ Oil and gas producers also pay governments huge sums for contracts as well as licence fees and taxes. Yet this wealth is often not translated into social and economic development in many of the resource-rich States for the considerable revenues that these produce are often the root cause of both grand corruption and the bribery of foreign public officials by transnational corporations. ${ }^{3}$ As the Commission for Africa has put it:

"It is not only the politicians and public officials who create the problem: it is also the corporations, bankers, the lawyers and the accountants, and the engineers working on public contracts". ${ }^{4}$

Given this reality, in seeking to address bribery on the supply side, new strategies are required. As Slapper puts it:

"This is a world in which the power and reach of transnational corporations is something that requires the development of a

\footnotetext{
1 In this context, the "private sector" is defined as "the sector of a national economy under private ownership in which the allocation of productive resources is controlled by market forces, rather than public authorities and other sectors of the economy not under the public sector or government", Article 1, African Union Convention on the Prevention and Combating of Corruption.

2 According to the World Bank, non-renewable mineral resources play a dominant role in 81 countries, which collectively account for a quarter of world GDP, half of the world's population, and nearly $70 \%$ of those in extreme poverty. Africa is home to about $30 \%$ of the world's mineral reserves, $10 \%$ of the world's oil, and $8 \%$ of the world's natural gas: see $<$ http://www.worldbank.org/en/topic/extractiveindustries/overview\#1 $>$ accessed 1 July 2016.

3 Revenue Watch Institute/Transparency International, Promoting Revenue Transparency: 2011 Report on Oil and Gas Companies (2011) 5.

${ }^{4}$ Commission for Africa, Our Common Interest (Commission for Africa 2005) 150.
} 
jurisprudence different from that which emerged in an earlier era..."

This article explores some of the developing strategies designed to tackle the supply side of transnational corruption through the "Art of Persuasion" i.e. how to "persuade" commercial organisations, no matter how powerful, to commit to good governance and integrity in their business. ${ }^{6}$ In doing so, it uses Alstom SA (hereinafter Alstom) as a case study. Alstom is headquartered in France and is involved in the engineering and, until recently, the energy sector. ${ }^{7}$ It operates via a series of subsidiaries through which it bids to secure contracts on projects around the world, some of which are funded by the World Bank and other international financial institutions. It has some 110,000 employees in over seventy countries. ${ }^{8}$

The article is divided into three parts. Part 1 explores some of "persuasive" techniques designed to combat the bribery of foreign public officials and to enhance corporate good governance and integrity. Part 2 explores some of the lessons and challenges from the Alstom case whilst Part 3 contains a Conclusion which re-visits the "Art of Persuasion".

\section{PART 1: THE “ART OF PERSUASION”}

Given their economic and political muscle, "persuading" commercial organisations, including even the most powerful transnational corporate entities (and however reluctantly), to act with integrity and to implement effective anti-bribery measures in their business activities is potentially extremely challenging. ${ }^{9}$

\footnotetext{
${ }^{5}$ Gary Slapper, "Violent Corporate Crime, Corporate Social Responsibility and Human Rights" in Aurora Voiculescu and Helen Yanacopulos (eds), The Business of Human Rights: An Evolving Agenda for Corporate Responsibility (Zed Books 2010) 81.

6 The term "commercial organisations" is used in the UK Bribery Act 2010 with reference to foreign bribery offences: see s 7(5)(c). In general, in this article it covers corporate entities and partnerships which carry on a trade, business or profession.

7 As noted below, the proposed sale of its energy business to GE was put in jeopardy due to Alstom's involvement in a series of global bribery scandals.

8 The information is drawn from the Statement of Facts contained in Alstom's Plea Agreement with the US Department of Justice in 2014: see United States $v$ Alstom SA Case 3:14-cr-00246-JBA.

9 KPMG, Anti-Bribery and Corruption: Rising to the Challenge in the Age of Globalization (KPMG 2015) 7.
} 
In practice the challenge is to "persuade" such entities, whether they want to or not, to

i. Take effective steps to prevent the bribery of foreign public officials in their business activities; and

ii. Reveal everything about any past involvement in such bribery.

There are a series of persuasive strategies that suggest that some progress can be, and is being, made in this regard. In essence these strategies consist of:

A. Moral persuasion: Persuading commercial organisations to develop and implement effective internal ethics and compliance mechanisms;

B. Gentle persuasion: Persuading commercial organisations to adhere to international standards on corporate good governance and integrity;

C. Forceful persuasion: Prosecuting those commercial organisations and their officials for their involvement in foreign bribery;

D. Persuasive threats: Encouraging commercial organisations to selfreport their wrongdoing backed up by threats if this is not done. ${ }^{10}$

\section{A. Moral Persuasion: Persuading commercial organisations to develop and implement internal ethics and compliance mechanisms}

Commercial organisations are increasingly concerned about their potential for exposure to reputational and litigation risks for a failure to prevent bribery within their global operations. In practice many have developed their own a code of ethics and anti-bribery programmes. ${ }^{11}$ This finds support in the United Nations Convention Against Corruption (UNCAC) which highlights the importance of:

"Promoting the development of standards and procedures designed to safeguard the integrity of relevant private entities, including codes of conduct for the correct, honourable and proper

10 For a general discussion see John Hatchard, Combating Corruption: Legal Approaches to Supporting Good Governance and Integrity in Africa (Edward Elgar, 2014) 335-345.

${ }^{11}$ In this context a "Programme" represents "the enterprise's anti-bribery efforts including values, code of conduct, detailed policies and procedures, risk management, internal and external communication, training and guidance, internal controls, oversight, monitoring and assurance": Transparency International, Business Principles for Countering Bribery (2013) Principle 2. 
performance of the activities of business ... and for the promotion of good commercial practices among businesses and in the contractual relations of businesses with the State". ${ }^{12}$

The publication of such codes and programmes highlights a public commitment on the part of the commercial organisation to corporate good governance. A good example is provided by Alstom itself:

"Our Code of Ethics is essential and all employees, in their day-today work, need to share the same clear values and observe the same rules of personal and collective conduct that define Alstom as an ethical company". ${ }^{13}$

In practice, the value of such codes and programmes is questionable and, as Transparency International (TI) has observed:

"[a]t their worst, corporate responsibility programmes may be mere window-dressing exercises. At their best, these initiatives represent genuine attempts by companies working with stakeholders to address the great environmental, social and ethical challenges of our times". ${ }^{14}$

As discussed below, the corporate codes of ethics and compliance programmes are reinforced by "gentle persuasion" initiatives.

\section{B. Gentle Persuasion: Persuading commercial organisations to adhere to international standards on corporate good governance and integrity}

There are now an impressive range of global standard-setting initiatives aimed at enhancing integrity and combating corruption in the

\footnotetext{
${ }^{12}$ Art 12(2)(b). Article 12(1) requires each State Party "in accordance with the fundamental principles of its legal system" to prevent corruption involving the private sector [and] enhance accounting and auditing standards.

13 The Alstom Code of Ethics is available at $<$ https://www.unglobalcompact.org/system/attachments/cop_2015/211831/origin al/AlstomCodeEthics_GB_2014_interactif_Oct14.pdf?1447744097> accessed 1 July 2016.

${ }^{14}$ Transparency International, Corporate Responsibility \& Anti-Corruption: the Missing Link? (TI Working Paper 01/2010) 1.
} 
private sector. ${ }^{15}$ Perhaps the best known is the United Nations Global Compact (UNGC) which is widely regarded as the world's largest corporate responsibility initiative. The UNGC consists of a set of voluntary norms consisting of ten Principles (the UNGC Principles). The $10^{\text {th }}$ Principle, which was adopted in 2004 , simply states:

"Businesses should work against corruption in all its forms, including extortion and bribery".

The Organisation for Economic Cooperation and Development (OECD) Guidelines for Multinational Enterprises and the Transparency International Business Principles for Countering Bribery (the Business Principles) contain similar principles. ${ }^{16}$

The Business Principles provide a blueprint for the development of effective corporate good governance and integrity. They are based on a Board commitment to the fundamental values of integrity, transparency, and accountability and the principle that "[e]nterprises should aim to create and maintain a trust-based and inclusive internal culture in which bribery is not tolerated". ${ }^{17}$ There is also a commitment by the "enterprise" to the implementation of a "Programme" to counter bribery. Given the realities of international business, the Business Principles also require the enterprise to extend its Programme to its subsidiaries and "use its influence to encourage an equivalent Programme in other business entities in which it has a significant investment or with which it has significant business relationships". ${ }^{18}$ Further it should take appropriate action in respect of joint ventures and consortia, contractors and suppliers and agents and representatives. ${ }^{19}$

Whilst these initiatives comprise recommendations, the UNGC involves some monitoring. Over 12,000 "business participants" in 170 countries have registered with the UNGC, with each making a

\footnotetext{
${ }^{15}$ For a detailed account of these initiatives, see Colin Nicholls, Tim Daniel, Alan Bacarese, James Maton and John Hatchard, Corruption and Misuse of Public Office ( $3^{\text {rd }}$ edn, OUP 2017) paras 13.04-13.58.

16 Principle 2 states that "The enterprise shall prohibit bribery in any form whether direct or indirect". The working definition of "bribery" adopted for the purposes of the Business Principles is: "The offering, promising, giving, accepting or soliciting of an advantage as an inducement for an action which is illegal or a breach of trust" 4 .

${ }^{17}$ Principle 2.

18 Para 5.2.1.

19 Alstom's use of subsidiaries and agents/consultants through which to pay bribes to foreign public officials is discussed below.
} 
commitment to integrate the Principles into their strategies and operations. All are required to produce an annual Communication on Progress $(\mathrm{CoP})$ which is a public self-assessment on progress made in implementing the UNGC Principles, and in supporting broad UN development goals.

Alstom joined the UNGC in 2008 and since 2011 has been categorised as an "active" member. Its annual CoP reports highlight its commitment to the UNGC Principles. For example, in 2012 it emphasised the fact that "Infringing laws, acting without business ethics and personal integrity inhibits innovation, increases costs, [and] impairs quality". Further, it announced that it had a Code of Ethics which was available in numerous languages and that it had also developed a training regime on ethics for its employees. ${ }^{20}$ Similarly, in its 2015 CoP report, the company highlighted its commitment to business ethics noting that the Alstom Integrity Programme was certified in 2011 and 2014 by ETHIC International and that as a member of the UNGC it was involved in initiatives and working groups on preventing corruption. ${ }^{21}$

On the face of it, such public affirmations suggest that the standard setting initiatives can influence the development of a "good governance" culture within commercial organisations. However to what extent this occurs in practice is questionable and this is highlighted in the case of Alstom (and its subsidiaries) which, as discussed below, has a lengthy record of bribe-paying on a global scale.

\section{Forceful Persuasion: Prosecuting those commercial organisations and their senior officials involved in foreign bribery}

The Commission for Africa has rightly demanded that:

“... rich nations should put in place a series of measures to ... deter their own companies from paying bribes in the first place. After all as the former Zairean dictator President Mobutu Sese Seko once reputedly said: 'It takes two to be corrupt - the corrupted and the corrupter'. And he should know".22

\section{The OECD Anti-Bribery Convention}

\footnotetext{
${ }^{20}$ See Alstom, Ethics and Compliance: Overall Risk Assessment (2012) 4.

21 Alstom, Activity and Sustainable Development Report 2014-2015 at 4. The report comprises part of the 2015 Alstom CoP report.

${ }^{22}$ Commission for Africa, (n 4) 31.
} 
The key initiative here is the OECD Convention on Combating Bribery of Foreign Public Officials in International Business Transactions (the OECD Anti-Bribery Convention). This came into force on 15 February 1999 and is concerned wholly with "active corruption" i.e. bribery on the supply side. Its significance is emphasised by the fact that the 41 parties to the Convention are involved in some two-thirds of world exports and almost 90 per cent of total foreign direct investment outflows. ${ }^{23}$

Article 1(1) states that:

"Each Party shall take such measures as may be necessary to establish that it is a criminal offence under its law for any person intentionally to offer, promise or give any undue pecuniary or other advantage, whether directly or through intermediaries, to a foreign public official, for that official or for a third party, in order that the official act or refrain from acting in relation to the performance of official duties, in order to obtain or retain business or other improper advantage in the conduct of international business".

For the purposes of the OECD Anti-Bribery Convention, a foreign public official means "any person holding a legislative, administrative or judicial office of a foreign country, whether appointed or elected; any person exercising a public function for a foreign country, including for a public agency or public enterprise; and any official or agent of a public international organization". ${ }^{24}$

In view of the economic interests and/or political pressure that might affect prosecutions, Article 5 makes it clear that investigations and prosecutions:

“... shall not be influenced by considerations of national economic interest, the potential effect upon relations with another state or the identity of the national or legal person involved".

Article 5 is supported by paragraph 6 of the Annex to the 1997 Revised Recommendations of the OECD Ministerial Council which

23 These comprise the thirty-five OECD member states plus Argentina, Brazil, Bulgaria, Colombia, Russian Federation and South Africa.

${ }^{24}$ Art 1(4)(a). 
stresses that "public prosecutors should exercise their discretion independently, based on professional motives". ${ }^{25}$

\section{The OECD Anti-Bribery Convention in practice}

The United States (US) through its Foreign Corrupt Practices Act 1977 and the United Kingdom (UK) through its Bribery Act 2010 are both actively implementing their Convention obligations.

\section{i) The Foreign Corrupt Practices Act}

The Foreign Corrupt Practices Act (FCPA) makes it unlawful for US persons to make a corrupt payment to a foreign public official for the purpose of obtaining or retaining business for or with, or directing business to, any person. ${ }^{26}$ What makes the FCPA so powerful is that these provisions also apply to issuers of securities listed and traded on a US exchange. ${ }^{27}$ In addition, the Act requires companies to keep accurate books and records and to establish and maintain adequate internal controls. Failure to do so constitutes a criminal offence. Until August 2014, Alstom's shares were listed on the New York Stock Exchange. Accordingly it was an "issuer" for the purposes of the FCPA. ${ }^{28}$

As discussed below, in practice, the significant penalties that can be imposed by a court under the FCPA means that commercial organisations are willing to reach a settlement with the two enforcement agencies, the Department of Justice (DoJ) and the Securities and Exchange Commission (SEC), to resolve foreign bribery case(s). Of particular significance here is

${ }^{25}$ Commentary 27 to the OECD Anti-Bribery Convention makes it clear that the decision must not be subject to improper influence by concerns of a political nature. Prosecutorial discretion may include the application of a public interest test but this is to be determined by the prosecutor.

${ }^{26}$ Curiously, the word "bribe" does not appear in the Act itself.

27 See generally Department of Justice FCPA:A Resource Guide to the US Foreign Corrupt Practices Act (DoJ 2015) $<$ https://www.justice.gov/sites/default/files/criminalfraud/legacy/2015/01/16/guide.pdf $>$ accessed 1 September 2016.

${ }^{28}$ For a full discussion on the FCPA see Colin Nicholls et al, Corruption and Misuse of Public Office (n 15) ch 20. For a useful discussion on FCPA enforcement cases involving energy issues in Africa see Sarah Banco et al, "AntiCorruption Initiatives in Africa" in Marc Hammerson and John C LaMaster (eds), Oil and Gas in Africa: A Legal and Commercial Analysis of the Upstream Industry (Globe Law and Business 2015) 157-163. 
that the wide jurisdictional provisions of the FCPA means that the DoJ frequently takes on the role of a "global enforcer". Indeed, in terms of fines, eight out of the top ten FCPA enforcement cases have been imposed on companies headquartered outside the US. As discussed below, one of those cases involved a DoJ investigation into allegations that Alstom had paid bribes to obtain business on a global scale. As a result, the company currently has the dubious distinction of being subjected to the highest fine ever imposed for a breach of the FCPA provisions. One of the reasons for the DoJ commencing the investigation was that there was no investigation into Alstom's affairs being undertaken by France, where the company has its headquarters.

\section{ii) The Bribery Act 2010}

The UK was subjected to significant and prolonged criticism by both the OECD Working Group on Bribery and non-governmental organisations following the decision by the Serious Fraud Office (SFO) not to prosecute BAe in respect of the Al Yamamah bribery case. ${ }^{29}$ However since 2012 a policy change has seen the SFO bringing a series of foreign bribery prosecutions against both commercial organisations and individuals. To date these have largely been brought under the pre-2010 bribery laws as the Bribery Act 2010 is not retrospective. As discussed below, several Alstom subsidiaries and senior officials are the subject of ongoing criminal proceedings in the UK.

Section 6 of the Bribery Act 2010 specifically prohibits the bribery of a foreign public official and is based of Article 1 of the OECD AntiBribery Convention. Significantly, section 7 introduces a strict liability of offence of "failing to prevent corruption". This provides:

(1) A relevant commercial organisation ('C') is guilty of an offence under this section if a person ('A') associated with $\mathrm{C}$ bribes another person intending-

(a) to obtain or retain business for $\mathrm{C}$; or

(b) to obtain or retain an advantage in the conduct of business for C. ${ }^{30}$

${ }^{29}$ For a full account see Colin Nicholls, Tim Daniel, Alan Bacarese and John Hatchard, Corruption and Misuse of Public Office ( $2^{\text {nd }}$ edn, OUP 2011) paras 7.208-7.220.

${ }^{30}$ The first conviction under section 7 came in December 2015 when the Sweett Group PLC pleaded guilty to a charge of failing to prevent an act of bribery 
The significance of the development of effective corporate codes of conduct and compliance programmes is highlighted in section 7(2):

(2) But it is a defence for $\mathrm{C}$ to prove that $\mathrm{C}$ had in place adequate procedures designed to prevent persons associated with $\mathrm{C}$ from undertaking such conduct.

In this context, the Ministry of Justice has published Guidance in the form of six Principles as to what constitute "adequate procedures" ${ }^{31}$ with one being that:

"The commercial organisation seeks to ensure that its bribery prevention policies and procedures are embedded and understood throughout the organisation through internal and external communication, including training that is proportionate to the risks it faces". 32

The Bribery Act also has a wide jurisdictional reach. It applies to UK companies and UK registered partnerships as well as overseas entities which carry on a business or part of a business in the UK. As Nicholls points out, the result is that "an overseas company can be prosecuted for failing to prevent bribery by a person performing services on its behalf irrespective of the nationality of the person offering the bribe, and even though the bribery is in relation to non-UK businesses and the bribery is committed entirely outside the UK". ${ }^{33}$

\section{iii) Other Parties to the OECD Anti-Bribery Convention}

Regrettably, the political will to prosecute foreign bribery cases is scarcely reflected elsewhere. All Parties to the OECD Anti-Bribery Convention have put in place domestic laws that criminalise the bribery of foreign public officials. However, the continuing low number of prosecutions in the majority of Parties raises concerns over the

intended to secure and retain a contract in the United Arab Emirates: see SFO Press Release, 19 February 2016 and see $\mathrm{n} 54$ below.

31 Ministry of Justice, The Bribery Act: Guidance about Procedures which Commercial Organisations can put in Place to Prevent Persons associated with them from Bribing (2011). This was published as required by section 9 of the Bribery Act 2010. For a full analysis see Nicholls et al, (n 15) paras 4.56-4.75.

32 Principle 5.

${ }^{33}$ Nicholls et al, (n 15) para 3.18. 
effectiveness of the Convention itself. This is reflected in the TI Annual Progress Report on the Implementation of the Convention 2015 which found that there was "Active enforcement" in only four convention

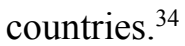

France, (where Alstom has its headquarters, it must be remembered), was categorised by TI in its 2014 report Exporting Corruption as having "Limited enforcement". This was a somewhat generous classification given that between 2011 and 2014 there were no major cases concluded which led to the imposition of sanctions. ${ }^{35}$ The TI report also highlights the fact that France continues to disregard the Article 5 provision and cites concerns over the perceived lack of independence of prosecutors from the Ministry of Justice. ${ }^{36}$ Certainly, it appears that neither Alstom nor any of its senior officials have been subject to any prosecution in France. ${ }^{37}$ Saenz's view seems to encapsulate the present position:

"France's ... general unwillingness to convict its own firms of foreign bribery offers little promise for change in the near future". ${ }^{38}$

Continuing pressure on all Parties for the use of forceful persuasion is highlighted in the OECD Ministerial Declaration of March 2016. Here "Ministers and Representative of the Parties to the OECD Convention" reaffirmed their commitment to the "robust enforcement of the laws implementing the foreign bribery offence by all Parties" and reiterated their commitment to Article $5 .{ }^{39}$ It remains to be seen whether this has any real impact on the political will on the part of all Parties to the OECD Anti-Bribery Convention to prosecute foreign bribery cases. Given this

\footnotetext{
34 These are Germany, Switzerland, the United Kingdom and the United States.

35 Transparency International, Exporting Corruption: Progress Report 2014: Assessing enforcement of the OECD Convention on Combating Foreign Bribery (2014) 2 .

${ }^{36}$ Ibid, 9 .

${ }^{37}$ Between 1999 and 2013, no "legal person" was either acquitted or sanctioned in France: see OECD Working Group on Bribery, Annual Report 2014, 18. But see $n 89$ below for a recent development.

38 Sara C Saenz, "Explaining International Variance in Foreign Bribery Prosecutions: A Comparative Case Study" (2015) 26 Duke Journal of Comparative \& International Law 271, 285. This reinforces the importance of the DoJ decision to bring FCPA enforcement action against Alstom.

${ }^{39}$ OECD Anti-Bribery Ministerial Meeting, Ministerial Declaration "The OECD Anti-Bribery Convention and its Role in the Global Fight against Corruption", 16 March 2016, para I.1.
} 
reality, the development of persuasive threats is a necessary complement to forceful persuasion.

\section{Persuasive Threats: Encouraging commercial organisations to self- report their wrongdoing}

Investigating and prosecuting foreign bribery cases is often extremely challenging, especially given the fact that, on the face of it, there is little or no incentive for those involved to reveal the corrupt bargain.

Whilst criticism of the failure by many Parties to the OECD AntiBribery Convention to prosecute foreign bribery cases effectively is justified, in recent years there has been a dramatic rise in the number companies being prepared to self-report their wrongdoing to the law enforcement authorities. In essence, the mere prospect of a conviction for a foreign bribery offence can in itself represent such a persuasive threat as to encourage commercial organisations to self-report any wrongdoing and seek a "deal" or settlement with prosecutors.

The key here is the threat of debarment (also known as blacklisting or exclusion). This is the mechanism through which a company or individual is prevented from tendering for, or participating in, a project(s) for a specific reason, such as previous involvement in corrupt practices. ${ }^{40}$ Debarment is now widely regarded as an important procedure for combating foreign bribery as it is fear of economic loss that constitutes such a persuasive threat that it drives the decision to self-report. Indeed an OECD study published in 2014 suggests that 1 in 3 foreign bribery cases were instigated by self-reporting by companies. ${ }^{41}$

Here the lead is being taken by both the US via the FCPA and the World Bank Group. Once again, Alstom provides an excellent case study.

\section{Alstom and the FCPA}

In 2014, the DoJ announced that investigations had revealed that Alstom "had paid more than US\$75 million [in bribes] to government officials in countries around the world, including Indonesia, Saudi Arabia, Egypt, the Bahamas and Taiwan, to secure US\$4 billion in projects with a

\footnotetext{
${ }^{40}$ See further John Hatchard, "Recent Developments in Combating the Bribery of Foreign Public Officials: A Cause for Optimism?" (2007) 85 University of Detroit-Mercy Law Review 1, 23-28.

${ }^{41}$ OECD Foreign Bribery Report: An Analysis of the Crime of Bribery of Foreign Public Officials (Paris 2014) 9.
} 
profit to the company of approximately US $\$ 300$ million". ${ }^{42}$ As a result, on 22 December 2014, Alstom pleaded guilty to charges of violating the FCPA by falsifying its books and records and failing to implement adequate internal controls.

On 22 December 2014, Alstom issued the following brief press release:

"Alstom S.A. has agreed to plead guilty to violating the books and records and internal controls provisions of the FCPA and to pay a fine of approximately US\$772 million".

It was left to the DoJ to provide the reasons for imposing the biggest fine ever levied for FCPA offences. These also serve as a warning to other commercial organisations to take persuasive threats seriously. ${ }^{43}$

1) Alstom failed to self-report: i.e. it failed voluntarily to disclose its misconduct. This clearly places the onus on the commercial organisation to take the initiative by self-reporting rather than adopting a "wait and see" approach as to whether their misconduct will be discovered.

2) Lack of cooperation by Alstom: Alstom initially failed to cooperate fully with the DoJ's investigation and this impeded the investigation of individuals involved in the bribery scheme.

3) Nature and seriousness of the offence: As the Plea Agreement puts it: "The Defendant's conduct spanned many years and a number of countries and business lines, and involved sophisticated high-level schemes to bribe government officials...". ${ }^{44}$

4) Alstom lacked an effective compliance and ethics programme at the time of the offence: This emphasises that simply having such a programme in place is not enough: commercial organisations must take steps to ensure that they are effective and subject to periodic review.

5) Prior corporate misconduct, including debarment of its subsidiaries by the World Bank (see below).

The Alstom Plea Agreement also includes detailed information about the alleged role of individual Alstom executives, employees and

\footnotetext{
42 DoJ Press Release, November 132015.

43 The full details of the Plea Agreement of 22 December 2014 are set out in United States $v$ Alstom SA Case 3:14-cr-00246-JBA.

${ }^{44}$ Ibid, 14.
} 
"consultants" in the bribery schemes. This is significant in that attention is not simply focused on the organisation as a legal person, but also on those within it who are responsible for the wrongdoing.

The desire on the part of Alstom to plead guilty to a non-bribery offence is of crucial importance. For commercial organisations, it is vital to avoid a bribery conviction which brings with it possible debarment proceedings in the US and the loss of US government contracts. Thus the threat of debarment and the dire economic consequences thereof, can "persuade" even the most powerful commercial organisations of the need to "reveal all" and to reach a settlement in foreign bribery cases.

\section{Alstom and the World Bank}

Much of the funding for major projects in developing countries is provided by the five multilateral development banks. ${ }^{45}$ In recent years, these institutions have paid increasing attention to combating fraud and corruption in the procurement process. The role of the World Bank Group (WBG) in this respect is particularly illustrative. ${ }^{46}$

The WBG has a strict policy on dealing with fraud and corruption in relation to WBG-financed projects. Its policy on "Fraud and Corruption" is set out in the Procurement Guidelines ${ }^{47}$ as follows:

"It is the Bank's policy to require that Borrowers (including beneficiaries of Bank loans), bidders, suppliers, contractors and their agents (whether declared or not), sub-contractors, subconsultants, service providers or suppliers, and any personnel thereof, observe the highest standard of ethics during the procurement and execution of Bank-financed contracts". ${ }^{48}$

45 The African Development Bank Group, the Asian Development Bank, the European Bank for Reconstruction and Development, the Inter-American Development Bank Group and the World Bank Group.

${ }^{46}$ The World Bank Group comprises five agencies: the International Bank for Reconstruction and Development (IBRD); International Development Agency (IDA); International Finance Corporation (IFC); Multilateral Investment Guarantee Agency (MIGA); and the International Centre for Settlement of Investment Disputes (ICSID). The term "World Bank" generally refers to the IBRD and the IDA.

${ }^{47}$ WBG Guidelines: Procurement of Goods, Works, and Non-Consulting Services under IBRD Loans and IDA Credits \& Grants by World Bank Borrowers, 2011, updated 2014.

${ }^{48}$ Para 1.16. 
A similar provision is found in the Consultants Guidelines.

A violation of the fraud and corruption provisions of the Procurement Guidelines or Consultants Guidelines renders a "Respondent" (i.e. a firm or individual) liable to sanctions. ${ }^{49}$ Article 9 of the WBG Sanctioning Guidelines provides for five possible sanctions:

a) A public letter of reprimand;

b) Conditional non-debarment: The Respondent is required to comply with certain remedial, preventative or other conditions as a condition to avoiding debarment from WBG projects;

c) Debarment for a fixed period; The Respondent is declared ineligible to tender for a WBG-funded project, either indefinitely or for a stated period of time;

d) Debarment with conditional release; The Respondent is released from debarment if the Respondent demonstrates compliance with certain remedial, preventative or other conditions for release, after a minimum period of debarment;

e) Restitution or Remedy: The Respondent is required to make restitution to the Borrower, to any other party or take action to remedy the harm done by its misconduct.

On 9 April 2010, the five multilateral development banks together with the International Monetary Fund and European Investment Bank Group (the Participating Institutions) signed an Agreement for Mutual Enforcement of Debarment Decisions (the Mutual Debarment Agreement). Under it, each agrees to enforce debarment decisions made by another Participating Institution as soon as possible. ${ }^{50}$ This coordinated and comprehensive approach to debarment is a significant milestone as it provides a common framework for tackling transnational corruption and provides another significant persuasive threat to the economic well-being of commercial organisations. ${ }^{51}$

The Alstom case neatly illustrates the debarment and cross-debarment process. In 2002 Alstom made an improper payment of $€ 110,000$ to an

49 The current listing of ineligible firms and individuals is available at $<$ http://web.worldbank.org/external/default/main?theSitePK=84266\&contentMD $\mathrm{K}=64069844 \&$ menuPK $=116730$ \&page $\mathrm{PK}=64148989 \& \mathrm{piPK}=64148984>$ accessed 1 July 2016.

${ }^{50}$ This is subject to the criteria set out in paragraph 4 of the Agreement.

${ }^{51}$ For a useful discussion on the 2010 Agreement see Lorenzo Nesti, "The 2010 'Agreement on Mutual Enforcement of Debarment Decisions' and Its Impact for the Fight Against Fraud and Corruption in Public Procurement" (2014) 14(1) Journal of Public Procurement 62-95. 
entity controlled by a former senior government official for consultancy services in relation to the WBG-financed Zambia Power Rehabilitation Project. Following Alstom's acknowledgment of misconduct in relation to the project, in 2012, Alstom Hydro France and Alstom Network Schweiz AG (Switzerland) and their affiliates were debarred by the World Bank for a period of three years. As a result, they were also subject to crossdebarment under the Mutual Debarment Agreement. This was all part of a negotiated resolution agreement between Alstom and the World Bank which also included a restitution payment by the two companies totalling some $\$ 9.5$ million. In addition, Alstom itself and its other affiliates were conditionally non-debarred. ${ }^{52}$

\section{Strengthening corporate compliance programmes}

The failure of Alstom to have in place an effective anti-corruption compliance programme was noted in both the agreement with the World Bank and the Plea Agreement with the DoJ. As part of the World Bank settlement, the World Bank's Integrity Compliance Office (ICO) required Alstom to implement a corporate compliance programme in line with the World Bank's integrity compliance guidelines. An independent compliance monitor was appointed to oversee the process. By 2014 the ICO was satisfied that this had been implemented and accordingly Alstom's subsidiaries were released from debarment. In an important illustration of cooperation and coordination, based on the ICO's findings, the DoJ did not then impose a compliance monitor in the FCPA proceedings.

It is regrettable, albeit perhaps not surprising, that Alstom's UNGC Communications on Progress makes no reference to these events (nor indeed to any of Alstom's global misconduct): thus bringing into question the value of such reports.

\section{PART 2: SOME LESSONS FROM THE ALSTOM CASE}

The Alstom case provides a number of vital lessons in the art of persuading commercial organisations to prevent involvement in foreign bribery in their business activities. This Part explores some of the key lessons.

${ }^{52}$ World Bank Press Release, 22 February 2012. 


\section{Recognising the growing importance of corporate codes of ethics and compliance programmes}

On the face of it, voluntary corporate codes of ethics and compliance programmes appear to constitute merely "moral persuasion". Alstom's code of ethics is a case in point. Some form of code was in place during the period of bribe paying by the company and its subsidiaries: yet it had little or no impact on the way in which the company went about its global bribery activities.

Today, such codes and programmes are far more significant. Thus the failure of Alstom to have in place an effective compliance programme was a factor in determining the enormous fine imposed upon it by the DoJ as well as influencing the terms of its negotiated settlement with the WBG. More generally, under the Bribery Act the existence of a code of ethics is an important factor in determining whether or not a commercial organisation has "adequate procedures" in place to prove it has a defence to a section 7 charge.

In the past, such codes and programmes may well have been ignored by company management and shareholders. This is not the case today with the pressure now on commercial organisations not only to have them in place but to make them effective. Moral persuasion has been reinforced by persuasive threats.

\section{Controlling the activities of sales agents and other third parties}

As Banco et al point out, multi-national companies can face serious challenges when seeking to obtain or retain business in the energy sector in many parts of the world. ${ }^{53}$ A particular challenge is controlling the activities of sales agents, subsidiaries and third parties. ${ }^{54}$ This is emphasised in a 2015 survey by KPMG International. This found that an increasing number of companies were finding corporate anti-bribery and corruption compliance highly challenging with their overriding concern relating to the auditing of third parties for compliance. This was due to the "very high proportion of bribes now paid either by third parties to the

\footnotetext{
${ }^{53}$ See Banco et al, (n 28) 152.

${ }^{54}$ For example, in the Sweett Group case the corrupt payments were made by its subsidiary company, Cyril Sweett International Limited to Khaled Al Badie, a senior official of AAAI to secure the award of a contract with AAAI for the building of the Rotana Hotel in Abu Dhabi. As noted below, such cases also help reveal the identities of those foreign public officials involved in the bribery scandal and lead to their possible prosecution.
} 
ultimate recipient or to seemingly unrelated parties acting on behalf of the ultimate recipient". ${ }^{55}$ This is confirmed by the OECD Working Group on Bribery which reported that 3 out of 4 cases analysed involved the use of intermediaries. ${ }^{56}$

The pressure on commercial organisations to address the problem of bribery by their agents is neatly illustrated by the Alstom case. For many years the company had used external "sales consultants" in a number of countries who were compensated on a "success fee" basis. ${ }^{57}$ In 2014 the danger of such a practice was highlighted by the US DoJ:

"In connection with the bidding on the power projects [in the Bahamas], ... Alstom retained Consultant I [whose] primary purpose was not to provide legitimate consulting services to Alstom and its subsidiaries but instead was to pay bribes [to a public official] who had the ability to influence the award of power contracts". 58

It is noteworthy that in 2014, the company announced that "in an effort to further reduce compliance risks to the Group and in line with Alstom achieving the highest ethical business standards, the company has decided to discontinue the hiring of such Sales Consultants". ${ }^{9}$ Other commercial organisations may well need to follow suit.

\section{Developing the global political will to combat the bribery of foreign public officials}

Combating the bribery of public officials effectively also requires the political will on the part of all States to take the necessary steps to tackle the problem. There are still far too many states that demonstrate "no political will" to do so, despite their having in place legislation in compliance with the OECD Anti-Bribery Convention. Here the work of

\footnotetext{
${ }^{55}$ KPMG International, Anti-bribery and Corruption (n 9) 7.

${ }^{56}$ OECD Foreign Bribery Report (n 41) 8.

${ }^{57}$ Alstom Press Release, January 172014.

${ }^{58}$ See the discussion below on the fate of the Bahamian official. Similarly, in the case of bribes paid to obtain a power contract in Indonesia, the DoJ has noted that to conceal the bribes, Alstom "retained two consultants purportedly to provide legitimate consultation on behalf of Alstom ... In reality, the primary purpose for hiring the consultants was to use the consultants to pay bribes to Indonesian officials": DoJ Press release July 17 2014. The Press Release includes fascinating details about how the bribes were allegedly paid.
}

${ }^{59}$ Alstom Press Release (n 57). 
Transparency International and the OECD Working Group on Bribery in seeking to improve this situation is particularly noteworthy.

However, the approach of the US and the UK is encouraging. Indeed, the extensive jurisdiction provided for in the FCPA and BA means that few transnational corporations can avoid the prospect of prosecution even where the alleged foreign bribery offence(s) took place elsewhere.

\section{Prosecuting individuals within the commercial organisation}

It is notoriously difficult to identify those individuals within a commercial organisation who were involved in the bribery of foreign public officials. As the Yates memorandum puts it:

"In large corporations, where responsibility can be diffuse and decisions are made at various levels, it can be difficult to determine if someone possessed the knowledge and criminal intent necessary to establish their guilt beyond a reasonable doubt. This is particularly true when determining the culpability of high-level executives, who may be insulated from the day-to-day activity in which the misconduct occurs". ${ }^{60}$

It is therefore necessary to "persuade" commercial organisations to disclose information about those of its officials and employees who were responsible for or involved in the acts of foreign bribery. If successful, this can provide a most powerful deterrent as it now exposes even their most senior officials to criminal or civil liability. In practice, the US has been willing to prosecute such individuals. For example, between 2012 and 2014, four senior officials of Alstom subsidiaries pleaded guilty to FCPA violations in respect of the awarding of a US\$118 million power contract in Indonesia known as the Tarahan project. ${ }^{61}$

To emphasise this commitment, in September 2015 the US Deputy Attorney General, Sally Yates issued an internal DoJ memorandum (the Yates memo) entitled "Individual Accountability for Corporate Wrongdoing". ${ }^{2}$ This states that:

${ }^{60}$ See $n 62$ below, at 2.

${ }^{61}$ See Department of Justice Press release, 17 July 2014. Marubeni Corporation, Alstom's consortium partner on the Tarahan project also pleaded guilty to conspiracy to violate the FCPA and was sentenced to pay a criminal fine of US\$88 million.

62 The Yates memorandum is available at $<$ https://www.justice.gov/dag/file/769036/download> accessed 1 July 2016 
"One of the most effective ways to combat corporate misconduct is by seeking accountability from the individuals who perpetrated the wrongdoing. Such accountability is important for several reasons: it deters future illegal activity, it incentivizes changes in corporate behavior, it ensures that the proper parties are held responsible for their actions, and it promotes the public's confidence in our justice system". ${ }^{63}$

The Yates memo provides "Guidance" which will apply to all future investigations of corporate wrongdoing. It makes it clear that, amongst other things:

(1) To be eligible for any cooperation credit, corporations must provide to the Department [of Justice] all relevant facts about the individuals involved in corporate misconduct; ${ }^{64}$

(2) Both criminal and civil corporate investigations should focus on individuals from the inception of the investigation; ${ }^{65}$ and

(3) Absent extraordinary circumstances, no corporate resolution will provide protection from criminal or civil liability for any individuals. $^{66}$

Given the already significant financial penalties being imposed on commercial organisations by the DoJ, this represents a most significant persuasive threat that requires commercial organisations to adopt a "reveal all" approach. Indeed, as noted earlier, one reason for Alstom's record fine was due to its failure to cooperate fully with the DoJ investigators.

In the UK, a somewhat similar approach is being taken with the SFO launching a series of prosecutions against several senior Alstom company executives in relation to the alleged payment of bribes paid in order to obtain business in India, Poland and Tunisia. ${ }^{67}$

\footnotetext{
${ }^{63}$ Ibid, 1

${ }^{64}$ Emphasis in the original.

${ }^{65}$ Guidance, para 2. The Yates Memo (at 2) states that the Guidance also applies to civil corporate matters as these "serve to redress misconduct and deter future wrongdoing".

${ }^{66}$ Guidance, para 4.

67 As at 1 November 2016, the cases were still ongoing. In some cases, the sharing of information between States is the catalyst for launching an investigation. For example, the SFO investigation which led to Alstom subsidiaries and senior company officials being charged with bribery offences in
} 
Given this reality, the EY $14^{\text {th }}$ Global Fraud Survey (the EY Global Fraud Survey) entitled Corporate Misconduct: Individual Consequences makes the position quite clear:

"Boards need to be aware that regulators are enforcing anticorruption legislation with vigor, and are increasingly focused on individual misconduct. Boards must respond and confirm that they are doing enough to protect their business from these risks, or both board members and their employees may be held personally responsible for misconduct under their watch". ${ }^{68}$

\section{Revealing the identity of the foreign public officials who benefitted from the bribe}

The "reveal all" approach demanded by self-reporting also helps to remove the secrecy surrounding the corrupt bargain itself and thus identify those foreign public officials involved in the bribery scandal. This provides the victim States with an opportunity to take appropriate action against those officials. For example, as noted earlier, Alstom pleaded guilty to bribery in connection with the obtaining of a contract with the Bahamas Electricity Corporation (BEC), a government-owned company. In May 2016, a court in the Bahamas convicted Fred Ramsey, a former board member of the BEC, of a series of bribery offences involving his assisting Alstom to obtain win contracts and overturn a government award to a competitor. It might be noted that the chief prosecution witness at the trial was the Alstom consultant who paid the bribes: he had been granted immunity in the case. ${ }^{69}$

\section{Dealing with prosecutions in multiple jurisdictions}

The Alstom case highlights the fact that by adopting (i.e. being "persuaded" to adopt) the "reveal all" approach may open the company to

Hungary commenced as a result of information supplied by the Office of the Attorney General in Switzerland: SFO Press Release 12 May 2015.

68 EY 14th Global Fraud Survey, Corporate Misconduct: Individual Consequences (2016) 4. The EY Survey also found that the majority of respondents supported the prosecution of individual executives with $83 \%$ of respondents viewing enforcement against management as an effective deterrent in combating corruption: 5 .

${ }^{69}$ Richard L Cassim, "Bahamas Utility Official Convicted of Taking Alstom Bribes" FCPA blog, 5 May 2016: $<$ http://www.fcpablog.com/blog/2016/5/5/bahamas-utility-official-convicted-oftaking-alstom-bribes.html> accessed 1 August 2016. 
enforcement actions in multiple jurisdictions or by multiple international financial institutions based on the same or similar facts.

Whilst not an "Alstom" case, the Bonny Island case provides a good illustration of such actions. This related to contracts for a natural gas project in Nigeria obtained by four foreign companies (the TSKL consortium) allegedly through bribery. The TSKL consortium later agreed a FCPA-related settlement with the DoJ and SEC and then, following an investigation in Nigeria, to a settlement with the Nigerian government. The consortium also agreed to pay penalties to the African Development Bank totalling US\$22.7 million for bribes relating to the same contracts whilst an Italian court also fined one of the partner companies to the consortium some US\$27.4 million. $^{70}$

In the Alstom case, its settlement with the US DoJ was to resolve charges that it paid bribes to government officials in Egypt, Saudi Arabia, the Bahamas and Taiwan. But there was no "global" settlement here. This raises the prospect of the company also facing prosecution (or other enforcement action) in these "victim" states with the prospect of significant additional financial penalties being imposed on it. If this is the case, then, without more, this can have a chilling effect on the reveal all approach as companies seek to avoid exposure to criminal liability on a global scale.

This is a developing area which raises two further issues.

\section{a) A global settlement approach?}

In cases where more than one Party has jurisdiction over the foreign bribery offence, Article 4(3) of the OECD Anti-Bribery Convention provides that "the Parties involved shall, at the request of one of them, consult with a view to determining the most appropriate jurisdiction for prosecution". Clearly there is no obligation to consult and the provision only applies to Parties to the Convention. The UNCAC, which has a global reach, ${ }^{71}$ takes a similar approach. It provides that "States Parties shall consider concluding bilateral or multilateral agreements or arrangements in relation to matters that are subject to investigations, prosecution or judicial proceedings in one or more States". ${ }^{72}$ Further that in such proceedings, "the competent authorities of those States Parties

\footnotetext{
${ }^{70}$ For details and sources of the information see Jay Holtmeier, "Cross-Border Corruption Enforcement: A Case for Measured Coordination Among Multiple Enforcement Authorities" (2015) 84 Fordham LR 493, 498-499.

${ }^{71}$ As at 1 November 2016, there were 180 State Parties to the Convention.

${ }^{72}$ Article 49.
} 
shall, as appropriate, consult one another with a view to coordinating the actions". ${ }^{73}$

Thus, there is no obligation on States to reach a global settlement and the possibility remains of carbon copy prosecutions ${ }^{74}$ of, or other enforcement action against, the commercial organisation in multiple States based on the same or similar conduct. ${ }^{75}$ This is potentially of particular value for victim States which have an opportunity of using the corporate disclosure to prosecute both their own corrupt public officials as well as the bribe paying company. ${ }^{76}$

The possibility remains of reducing corporate financial liability in the light of a monetary settlement reached in another State or of coordinated action between States to resolve a global bribery issue. ${ }^{77}$ However whether any "credit" is given by a court in response to such a settlement is uncertain.

\section{b) A double jeopardy issue?}

The double jeopardy rule was developed by the common law to prevent a person being tried twice for the same crime and is widely recognised in both national laws and international conventions. Yet the rule is potentially limited by the dual sovereignty principle which provides that two sovereign States can each prosecute a person for the violation of both their laws even if based on the same facts. As Colangelo asserts:

"A national prosecution applying and enforcing a national law does not erect a bar to successive prosecutions by other States with national jurisdiction over the crime in question". ${ }^{78}$

\footnotetext{
73 Article 42(5).

74 A term coined in Andrew S Boutros and T Markus Frank, "Carbon Copy' Prosecutions: A Growing Anti-Corruption Phenomenon in a Shrinking World" [2012] U Chicago Legal Forum 259, 260.

75 Alstom's plea agreement with the DoJ specifically states that it is only binding on the DoJ: see United States v Alstom SA 14-CR-236 (2014), para 3 (the Alstom settlement).

${ }^{76}$ An excellent example of this is provided by the Lesotho Highlands Water case: see Hatchard, Combating Corruption (n 10) 245 et seq.

77 For example, in the Siemens case, the company entered into a coordinated settlement with both the DoJ and German authorities. For a useful discussion on this area see Holtmeier (n 70) 508-511.

78 Anthony J Colangelo, "Double Jeopardy and Multiple Sovereigns: A Jurisdictional Theory” (2009) 86 Washington University Law Review 769, 797.
} 
For example, in a case involving a Siemens employee, the defendant sought to have a corruption charge dismissed in an Argentinian court on the basis that he had previously been prosecuted for the same offence in Germany. The court refused to dismiss the case ruling that the German court had focused on the private effects of the alleged bribery whilst the Argentina case involved potential harm to the public sector. ${ }^{79}$ As Holtmeier comments:

"Thus, as conceived, the double jeopardy principle is narrow enough that if courts and enforcement agencies can find some way to distinguish the separate proceedings, and show they are not identical, it will rarely be a bar to prosecution" ${ }^{80}$

\section{Civil action by unsuccessful rival bidders}

The "reveal all" requirement may also leave commercial organisations open to the prospect of civil actions being brought against them by unsuccessful bidders for contracts which were won through bribery. ${ }^{81}$ For example, at the trial of Fred Ramsey in the Bahamas, the Alstom agent responsible for the payment of the bribes testified that these were paid in return, amongst other things, for Mr Ramsey asking a Cabinet minister to intervene to overturn a unanimous decision of the BEC to award the contract to a South Korean company, Han Jung. ${ }^{82}$ In such circumstances, there seems little to prevent Han Jung bringing civil proceedings against Alstom.

\section{Encouraging whistleblowing}

The United Nations Office on Drugs and Crime (UNODC) has noted that there is extensive research to demonstrate that information provided

Emphasis in the original. The article provides a detailed examination of the issue: see especially 790-805.

${ }^{79}$ This information is drawn from Lucio Fabiani Larranga. "Double Jeopardy? Siemens Defendant Loses Argentina Dismissal Motion": see further $<$ http://www.fcpablog.com/blog/2015/7/21/double-jeopardy-siemens-defendantloses-argentina-dismissal.html> accessed 1 July 2016.

${ }^{80} \mathrm{Ibid}, 515$. Emphasis in the original.

${ }^{81}$ See, for example, the South African case of Transnet Ltd $v$ Sechaba Photoscan (Pty) Ltd [2004] ZASCA 24 and discussed in Hatchard, Combating Corruption (n 10) $258-259$.

${ }^{82}$ See Holtmeier (n 70) 498. 
by whistleblowers is one of the most common ways in which instances of fraud and corruption are identified. ${ }^{83}$ It is therefore not surprising that the international community is taking active steps to encourage both whistleblowing and the provision of effective protection for those who do so. ${ }^{84}$

Given this reality, the possibility of whistleblowers revealing corporate wrongdoing is increasingly a threat to commercial organisations. The potential impact of whistleblowing is neatly illustrated by the HSBC Bank case in which Hervé Falciani leaked financial documents showing illegal activities by the Swiss arm of the bank. ${ }^{85}$ The release of the Panama Papers in 2016 even more starkly highlights the possibility of the "super-whistleblower" who is capable of obtaining vast quantities of data with potentially explosive exposure of nefarious corporate wrongdoing. Indeed, commercial organisations can also expect to be exposed to new risks of data loss through cyber attacks. ${ }^{86}$

There is seemingly no mention of Alstom in either of the leaks. However, the threat of exposure of corporate wrongdoing by whistleblowers, either voluntarily or by way of a plea bargain (or through cyber attacks), and its potential economic impact on any commercial organisation is another potentially significant persuasive threat to encourage good corporate governance. ${ }^{87}$

${ }^{83}$ UNODC, The United Nations Convention against Corruption: Resource Guide on Good Practices in the Protection of Reporting Persons (UNODC 2015) 3. This publication contains an excellent bibliography on the wealth of resource material available on this topic.

${ }^{84}$ See, for example, the Council of Europe, Recommendation on the Protection of Whistleblowers (Committee of Ministers Recommendation to Member States $\mathrm{CM} / \operatorname{Rec}(2014) 7)$. For the purposes of the Recommendation, a whistleblower means "any person who reports or discloses information on a threat or harm to the public interest in the context of their work-based relationship, whether it be in the public or private sector": Appendix.

${ }^{85}$ For his trouble, in 2015 Falciani was convicted by a Swiss court of offences relating to his action and sentenced to five years imprisonment.

${ }^{86}$ See the EY Global Fraud Survey (n 68) 41.

87 For example, in June 2016, both Alstom and GE were named by a whistleblower as being involved in the Petrobras bribery case. The information was provided by way of a plea bargain. Both denied any involvement in the case but Alstom's shares fell 2.7\% on the news: Bloomberg News, 7 June, 2016. 


\section{Requiring enhanced scrutiny of commercial organisations subject to mergers or acquisitions}

Commercial organisations are now under pressure to perform enhanced due diligence when involved in mergers and acquisitions. This, in itself, can raise concerns about possible misconduct on the part of the other party which can delay or even undermine the proposed deal. For example, at the time of the DoJ investigation into its activities, Alstom was in the process of seeking to sell its energy business to the giant American firm GE for around US\$15 billion. This was put on hold until the deal by Alstom with the US Department of Justice paved the way for the sale to proceed. Even then Alstom was not permitted to pay the US\$772 million fine from the proceeds of the merger.

According to the EY Global Fraud Survey, despite record levels of mergers and acquisitions: "... respondents are not yet taking potential steps to identify and mitigate key corruption risks before entering into joint ventures or local partnerships" ${ }^{88}$ Clearly there is still progress to be made here.

\section{PART 3: CONCLUSION: THE ART OF PERSUASION REVISITED}

This article has explored the challenge of persuading commercial organisations whether they want to or not, to

(1) Take effective steps to prevent the bribery of foreign public officials in their business activities (the prevention strategy); and

(2) Reveal everything about any past involvement in such bribery (the reveal all strategy).

Using the case of Alstom, it has highlighted that there are a range of persuasive techniques that can meet this challenge.

As regards the prevention strategy, the moral persuasion approach i.e. persuading commercial organisations to publicly commit to corporate good governance through putting in place codes of ethics and compliance programmes, may seem of limited value. As TI points out, at worst such programmes are "mere window dressing" exercises. Certainly, in the light of its diverse foreign bribery activities, Alstom's claim to be an "ethical company" has a somewhat hollow ring.

${ }^{88}$ EY Global Fraud Survey (n 68) 25. 
Yet today, the development of corporate codes of conduct and compliance programmes goes beyond moral persuasion and mere window dressing. There is now real pressure on all commercial organisations to take steps to maintain a "rigorous anti-corruption compliance programme that includes policies and procedures designed to detect and deter violations" of anti-bribery laws. The "gentle persuasion" standard-setting initiatives of the UNGC, the OECD and TI provide an excellent basis for the development and maintenance of such programmes. This will be enhanced if the Communications on Progress required under the UNGC are used to encourage, and help monitor transparency on, progress in this regard. With the moral persuasion and gentle persuasion strategies now being reinforced by persuasive threats, the hope is that commercial organisations will indeed take the necessary steps to prevent the bribery of foreign public officials in their business activities.

As regards the "reveal all" strategy, a combination of forceful persuasion and persuasive threats led to Alstom eventually disclosing its global bribery activities. However the impact of the forceful persuasion strategy remains limited by the reluctance of many Parties to the OECD Anti-Bribery Convention to prosecute cases of alleged foreign bribery. The failure of France to take any action against Alstom, a company that has its headquarters in that country, epitomises the point. The active enforcement of the Convention by all Parties is now essential and this will not only act as an important deterrent but should also facilitate the development of more effective multi-jurisdictional coordination in combating foreign bribery, including encouraging and facilitating a "global settlement" approach. ${ }^{89}$

Yet as the Alstom case highlights, it is the threat of a conviction for a foreign bribery offence and subsequent debarment that played the key role in persuading it to reveal all and to agree settlements with the World Bank and the US DoJ. In the US context, the Yates Memo now becomes highly significant. By making eligibility for a settlement dependent upon the commercial organisation providing the DoJ with "all the relevant facts about the individuals involved in corporate misconduct", it enhances the prospect of making accountable those responsible for the authorising

89 It is noteworthy that on November 8 2016, France adopted anti-corruption legislation (known as "Sapin 2") which allows magistrates to enter into deferred prosecution agreements with companies with the maximum fine being $30 \%$ of the company's annual turnover. To ensure transparency, the agreement requires the approval of a judge at a public hearing: see <http://www.reuters.com/article/usfrance-corruption-idUSKBN1332G1 ?feedType $=$ RSS\&feedName=worldNews $>$ accessed 9 November 2016. 
and/or undertaking the illegal activity as well as those in the highest echelons of the organisation who turn a "blind eye" to corporate wrongdoing. It also acts as an important deterrent on any future illegal activity and provides a further incentive for senior officials of commercial organisations to ensure that their compliance programmes are effectively implemented. This approach should be adopted elsewhere.

The Yates memo has drawn some criticism. One commentator describes it as "rhetoric because the reality is that few DOJ corporate enforcement actions result in any related charges against company employees. ${ }^{90}$ However only time will tell whether this is the case. What is important is that the policy is in place. As Yates herself has noted "Our goal is to get to the bottom of who did what and if there are culpable individuals, hold them accountable... Our goal is to uncover the truth". ${ }^{91}$

These are exciting times. Just a few years ago, the idea that commercial organisations, including even the largest multinationals, could be persuaded to take effective steps to prevent foreign bribery in their operations, whether they wanted to or not, would have seemed highly unlikely. This article has demonstrated that through the Art of Persuasion, corporate conduct can be changed for the better. This is still work in progress ${ }^{92}$ but hopefully it will contribute to the enhancement of good governance and transparent management in the energy sector

\footnotetext{
${ }^{90}$ See FCPA Professor blog <http://fcpaprofessor.com/the-yates-memo/> accessed 1 September 2016. It is further asserted in the blog that between "2008$2014,75 \%$ of DOJ corporate enforcement actions have not (at least yet) resulted in any DOJ charges against company employees" (emphasis in the original). ${ }^{91}$ Speech given by Sally Q Yates at the New York City Bar Association White Collar Crime Conference, (May 17 2016) 5.

${ }^{92}$ For example, the results of the EY $14^{\text {th }}$ Global Fraud Survey show that "a significant minority of global executives [are] willing to justify unethical conduct" with the Report concluding that "individuals, including some senior executives entrusted with the guardianship of their firms, cannot be assumed to act with integrity if the end might seem to justify the means": see (n 69) 20 and 41.
} 